
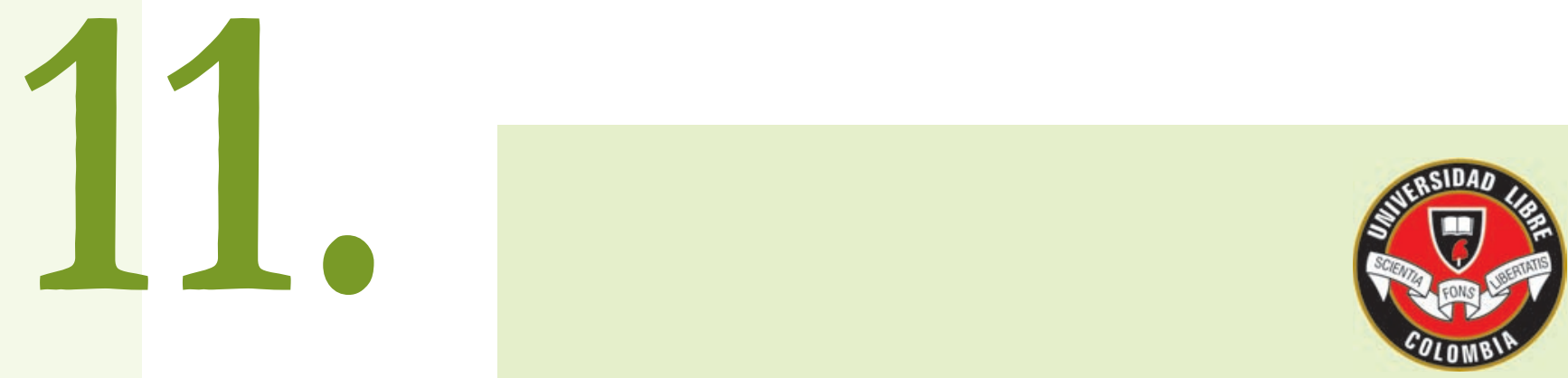

La Calidad Académica, un Compromiso Institucional

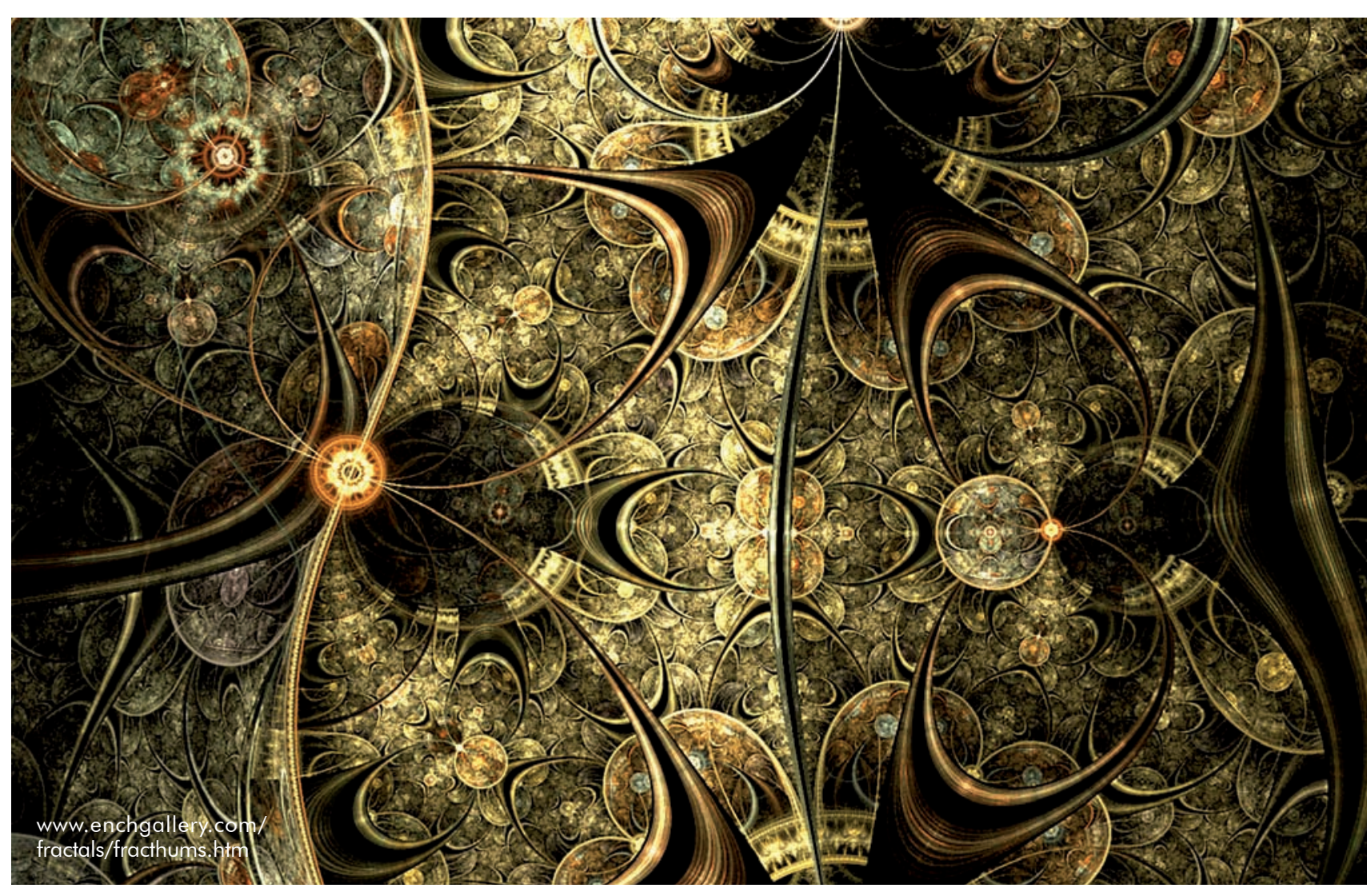

Fajardo-Calderón, Constanza L. y Suárez A., Dora C. (2012). Análisis comparativo del impuesto de renta para las personas naturales (Colombia) personas físicas (España) y los no residentes Criterio Libre, 10 (17) 235-258

ISSN 1900-0642
Análisis comparativo del impuesto de renta para las personas naturales (Colombia) - personas fúsicas (España) y los no residentes

Constanza Loreth Fajardo-Calderón Dora Cecilia Suárez Amaya 


\section{ANÁLISIS COMPARATIVO DEL IMPUESTO DE RENTA PARA LAS PERSONAS NATURALES (COLOMBIA) - PERSONAS FÍSICAS (ESPAÑA) Y LOS NO RESIDENTES"}

COMPARATIVE ANALYSIS OF INCOME TAX FOR ENTITIES (COLOMBIA), INDIVIDUALS (SPAIN), AND NON RESIDENTS

ANÁLISE COMPARATIVA DO IMPOSTO DE RENDA PARA AS PESSOAS NATURAIS (COLÔMBIA) PESSOAS FÍSICAS (ESPANHA) E OS NÃO RESIDENTES

\section{CONSTANZA LORETH FAJARDO-CALDERÓN DORA CECILIA SUÁREZ AMAYA§}

Artículo producto de investigación, correspondiente al Proyecto de análisis comparativo de impuestos de carácter Nacional del Derecho tributario de Colombia y el Derecho tributario de España, en el cual colaboraron, entre otras, las alumnas Lina María Maya Idárraga y Sandra Marcela Baquero Osorio.

This article belongs to the Tax Law Comparative Analysis Project in collaboration with students Lina María Maya Idárraga and Sandra Marcela Baquero Osorio among others. Artigo produto de pesquisa, correspondente ao Projeto de análise comparativo de impostos de carácter Nacional do Direito tributário da Colômbia e o Direito tributário da Espanha, no qual colaboraram, entre outras, as alunas Lina María Maya Idárraga e Sandra Marcela Baquero Osorio.

Article de recherche produit pour du Project de Benchmarking d'impôts au niveau national de droit fiscal en Colombie et en Espagne, qui a collaboré. Ce projet a été aussi élaboré par les étudiants Lina Maya Idarraga et Sandra Marcela Baquero Osorio.

‡ Contadora pública, Universidad del Quindío, Armenia, Colombia. Magíster en educación - docencia, Universidad de Manizales, Colombia; especialista en ciencias tributarias, Universidad del Quindío, Armenia, Colombia; especialista en control fiscal para entidades públicas, Universidad del Quindío; directora de la especialización en gerencia tributaria, Universidad La Gran Colombia, Armenia, Colombia; docente de planta de la Facultad de Ciencias Económicas y administrativas, Programa de Contaduría. Universidad del Quindío.lorethfa1@yahoo.es

Public Accountant, Quindío University, Armenia, Colombia. Master in Education - Teacher, Manizales University, Colombia; Tax Science Specialist, Quindío University, Armenia, Colombia; Tax Control for Public Entities Specialist, Quindío University, Specialization in Tax Management Program Director, La Gran Colombia University, Armenia, Colombia; Teacher, Economic and Administrative Science Faculty, Accounting Program, Universidad del Quindío University. lorethfa1@yahoo.es

Contadora pública, Universidade del Quindío, Armenia, Colômbia. Mestre em educação - docência, Universidade de Manizales, Colômbia; especialista em ciências tributárias, Universidade del Quindío, Armenia, Colômbia; especialista em controle fiscal para entidades públicas, Universidade del Quindío; diretora da especialização em gerência tributária, Universidade La Gran Colombia, Armenia, Colômbia; docente titular da Faculdade de Ciências Econômicas e administrativas, Programa de Contadoria. Universidade del Quindío. lorethfa1@yahoo.es

Criterio Libre $\mathrm{N}^{\circ} 17$

Bogotá (Colombia) Julio-Diciembre 2012

Pp. $235-258$ ISSN 1900-0642 


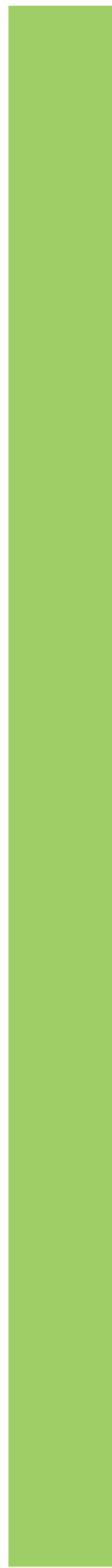

Fecha de recepción: noviembre 6 de 2011

Fecha de aceptación: abril 14 de 2012

Reception Date: November 62011

Acceptance Date: April 142012

Data de recepção: 6 de novembro de 2011

Data de aceitação: 14 de abril de 2012

Reçu le: Novembre 6, 2011

Accepté: Avril 14, 2012

RESUMEN

El estudio realizado desde el semillero de investigación de tributaria SITUQ logra desarrollar el trabajo de investigación "Análisis comparativo de impuestos de carácter nacional del Derecho Tributario de Colombia y el Derecho Tributario de España", en el cual se comprenden los sistemas tributarios; se establece el estado del arte de los impuestos de carácter nacional; se construye un análisis comparativo de sus diferencias y similitudes. De igual forma se analizan los efectos en los mismos al considerar el "Convenio entre el Reino de España y la República de Colombia para evitar la doble imposición y prevenir la evasión fiscal en materia de impuestos sobre la Renta y sobre el Patrimonio".

El presente artículo da cuenta de uno de los objetivos propuestos, en donde se logra conocer cómo es el sistema impositivo del impuesto sobre la renta en España y el impuesto sobre la renta en Colombia, para luego establecer diferencias y similitudes.

Comptable à I'Université de Quindio, Armenia - Colombie. Master en Education Université de Manizales en Colombie, spéciliste en suivi fiscal Université de Quindio. Directrice des études en gestion fiscalité, Université La Gran Colombia. Professeur de la Faculté des sciences économiques et administration du programme de comptabilité. Université de Quindio. lorethfa1@yahoo.es

\& Contadora pública, Universidad del Quindío, Armenia, Colombia; especialista en ciencias tributarias, Universidad del Quindío. Estudios de maestría en gestión empresarial con énfasis en gerencia tributaria y auditoría de impuestos; docente de la Facultad de Ciencias Económicas y administrativas, Programa de Contaduría, Universidad del Quindío.doracecilias@latinmail.com

Public Accountant, Quindío University, Armenia, Colombia. Tax Science Specialist, Quindío University. Master studies in management, emphasized in Tax management and auditing. Teacher, Economic and Administrative Science Faculty, Accounting Program, Quindio University. doracecilias@latinmail.com

Contadora pública, Universidade del Quindío, Armenia, Colômbia; especialista em ciências tributárias, Universidade del Quindío. Estudos de mestrado em gestão empresarial com énfase em gerência tributária e auditoria de impostos; docente da Faculdad de Ciências Econômicas e administrativas, Programa de Contadoria, Universidade del Quindío.doracecilias@latinmail.com

Comptable Université de Quindio, Armenia - Colombie. Master en gestion des entreprises. Professeur à la Faculté d'Economie et administration du programme de comptabilité. Université de Quindio. doracecilias@latinmail.com 
Lo anterior es de interés para la comunidad académica y profesional, quienes pueden abordar los hechos económicos y fiscales en un ambiente competitivo que exige el mundo actual.

PALABRAS CLAVE:

Renta, hecho imponible, base gravable, deducciones, compensaciones, cuota tributaria, deuda tributaria.

CLASIFICACIÓN JEL:

E62, E63, H30, M48, M49.

SUMMARY

"Comparative Analysis of National Taxes in Tax Law in Colombia and Tax Law in Spain" is a study that comes from SITUQ tax research center. In this study you will find tax systems, an establishment of the state of the art in national taxes, and a comparative analysis of its common grounds and its differences. Likewise, an analysis is made on the "Agreement between the Kingdom of Spain and the Republic of Colombia to avoid double imposition and prevent fiscal evasion in income and equity taxes" to measure its effects. The present article shows us how an imposition system is held on tax income in both countries to establish their differences and similarities. This is interesting for both academic and professional communities who may study economic and fiscal facts in the competitive environment of the modern world.

Key words: Income, imposition factor, deductions, compensations, fiscal basis. JEL Classification: E62, E63, H30, M48, M49.

RESUMO

O estudo realizado a partir da oficina de pesquisa tributária SITUQ logra desenvolver o trabalho de pesquisa "Análise comparativa de impostos de carácter nacional do Direito Tributário da Colômbia e o Direito Tributário da Espanha", no qual se compreenden os sistemas tributários; estabelece-se o estado de arte dos impostos de carácter nacional; construi-se uma análise comparativa de suas diferenças semelhanças. De igual forma analizam-se os efeitos nos mesmos ao considerar o "Convênio entre o Reino da Espanha e a República da Colômbia para evitar a dupla taxação e prevenir a evasão fiscal em matéria de impostos sobre a renda e sobre o Patrimônio".

$\bigcirc$ presente artigo alcança um dos objetivos propostos, no ponto onde consegue conhecer como é o sistema impositivo do imposto sobre a renda na Espanha e o imposto sobre a renda na Colômbia, para logo estabelecer diferenças e semelhanças. 


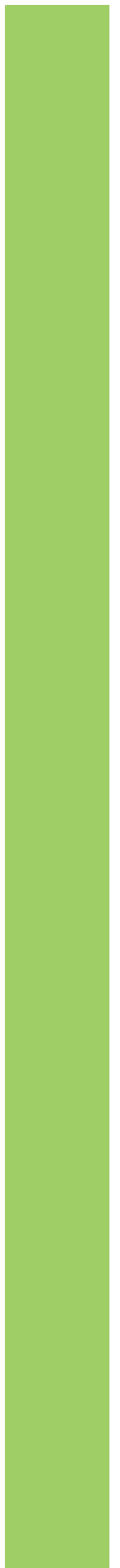

O anterior é de interesse para a comunidade acadêmica e profissional, os quais podem abordar os feitos econômicos e fiscais em um ambiente competitivo que exige o mundo atual.

Palavras chave: Renda, feito imponível, base gravável, deduções, compensações, cota tributária, dívida tributária. Classificação JEL: E62, E63, H30, M48, M49.

RÉSUMÉ

L'étude du groupe de recherche SITUQ a réussit à développer le projet de recherche "Analyse comparative de l'impôt national Droit fiscal en Colombie et en Espagne», qui comprennent les systèmes fiscaux, instituant la état de I'art des impôts nationaux, pour construire une analyse comparative de leurs différences et les similitudes.

De la même façon, les auteurs réfléchissent sur les effets de I '«Accord entre le Royaume d'Espagne et la République de Colombie en vue d'éviter les doubles impositions et de prévenir l'évasion fiscale en matière d'impôts sur le revenu et sur la fortune.»

Cet article rend compte de l'un des objectifs, où il est possible de savoir comment le régime fiscal de l'impôt sur le revenu en Espagne et l'impôt sur le revenu en Colombie, en vue d'établir les différences et les similitudes.

Ceci est d'intérêt pour la communauté universitaire et professionnel qui peut répondre aux faits économiques et budgétaires dans un environnement concurrentiel qui exige le monde d'aujourd'hui.

Mots-clés: Le revenu, l'événement imposable, du revenu imposable, les déductions, les allocations, la responsabilité fiscale, la dette fiscale. Classification JEL: E62, E63, H30, M48, M49.

"Todos pedimos que se aplique la Ley, y todos tratamos de eludir el cumplimiento de alguna".

AlAIN

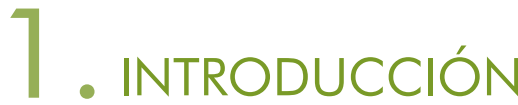

El desarrollo y globalización de la economía y la política, que cada vez más disminuye la soberanía de los Estados, haciendo necesaria una definición clara de los principios y las reglas aplicables a los agentes económicos que operan en diversas jurisdicciones tributarias. Pero esto ha generado la doble tributación internacional, que se da cuando dos países se encuentran involucrados en el cobro del impuesto al mismo sujeto pasivo, cuando el contribuyente es residente según las leyes de los dos países o cuando el residente tiene la fuente de su ingreso fuera del país de su residencia. 
"El desarrollo y globalización de la economía y la política, que cada vez, más disminuye la soberanía de los Estados, baciendo necesaria una definición clara de los principios y las reglas aplicables a los agentes económicos que operan en diversas jurisdicciones tributarias. Pero esto ha generado la doble tributación internacional, que se da cuando dos países se encuentran involucrados en el cobro del impuesto al mismo sujeto pasivo, cuando el contribuyente es residente según las leyes de los dos países o cuando el residente tiene la fuente de su ingreso fuera del país de su residencia."
Por lo anterior, los profesionales deben ser capaces de resolver asuntos jurídico tributarios propios del entorno internacional en el cual se involucran los derechos internos de varios países, los principios y normas del Derecho colombiano e internacional y normas emanadas de organizaciones internacionales. Con el trabajo de investigación "Análisis comparativo de impuestos de carácter nacional del Derecho tributario de Colombia y el Derecho tributario de España" se recoge las inquietudes académicas y de formación desde el semillero de tributaria y pretende establecer el estado del arte de la mayoría de los impuestos reglamentados en Colombia, para iniciar un proceso de evaluación, análisis y comparación entre diferentes países, y de esta manera identificar diferencias y semejanzas tributarias entre estos para proyectar las empresas productivas y orientar a los profesionales al mercado internacional.

El trabajo de investigación se desarrolla teniendo en cuenta los siguientes componentes: el problema de investigación, sus antecedentes, conceptualización, impacto esperado y planteamiento del problema. Los objetivos, tanto el general como los específicos; la justificación del proyecto de investigación; la metodología utilizada para la realización del proyecto; el marco teórico, el análisis de los resultados del trabajo de campo y, por último, las conclusiones y recomendaciones. Producto de este trabajo son varios textos escritos por las investigadoras principales y varios artículos producto del mismo proceso investigativo.

El artículo presenta el desarrollo de uno de los objetivos del trabajo final de la investigación, con el cual se logra dar a conocer los elementos tributarios básicos del impuesto sobre la renta de las personas naturales en Colombia y de las personas físicas en España y posteriormente mostrar un cuadro comparativo que permita identificar diferencias y similitudes del impuesto en los dos países. 


\subsection{ANTECEDENTES}

La cuna del impuesto sobre la renta se puede ubicar en el año 1797 en Inglaterra, en donde se ha conocido siempre con el nombre de Income Tax. Pero no era porque las instituciones fiscales inglesas vigentes en los primeros momentos de la aparición del impuesto fuesen las más apropiadas para darle entrada a una reforma de esa especie, sino porque la necesidad y el buen sentido práctico de los estadistas ingleses lograron imponerla.

En la Carta Magna, uno de los más importantes y trascendentales documentos que registra la historia inglesa, se encuentra como origen del impuesto de renta el hecho de que los nobles ingleses, en su alianza con el rey para gobernar y explotar al pueblo, se convencieron de que el monarca tomaba para sí la mayor parte del producto de las exacciones que se hacían a los vasallos y les dejaba a aquellos una cuota mínima, resolvieron ponerse en rebeldía, negándose primero a acompañar al rey en sus empresas bélicas y haciéndose luego renuentes a pagar los nuevos tributos exigidos para los gastos de la guerra. El rey Juan se mostró remiso al comienzo y concitó contra los nobles al clero del país, al que atrajo otorgándole el derecho del voto, y a los ciudadanos de Londres por medios análogos. Pero los nobles no retrocedieron en la lucha, y el rey, que era hombre de buen sentido y que necesitaba de ellos, terminó por capitular y entrar en arreglos con sus aliados insurrectos, quienes consiguieron hacerle firmar en junio de 1215 el memorable documento que se ha llamado desde entonces la Magna Carta de los ingleses. El rey dio en garantía de las promesas contenidas en ella, la tenencia a favor de los nobles en la ciudad de Londres.

Las declaraciones, promesas y estipulaciones de la magna Carta más bien que la base fundamental de sabias instituciones fiscales son muestra y claro exponente de las que hasta entonces regía, que se trataba de enmendar y corregir por medio de limitaciones la arbitrariedad del monarca. Allí se fijaron las sumas que debían pagar al rey los herederos de sus vasallos que este percibía antes sin limitación alguna; se determinó lo que podía tomar para sí del patrimonio de los menores de los cuales era guardador nato y a quienes muchas veces reducían a la mendicidad; lo que podía percibir de los bienes de las viudas, que él administraba y la obligación en que instaba de devolver el resto; la fijación de multas que antes se imponían discrecionalmente y constituían una fuente de ingresos del tesoro real.

Ningún impuesto nuevo se podía establecer de acuerdo con una de las disposiciones de la magna Carta sin el consentimiento del Consejo general de la Nación, formado por representantes de los nobles, del clero y del rey; pero al pueblo no se le dejaba la más ligera intervención en materia de contribuciones, pues la esencia de la reforma no tenía por objeto mejorar la condición del mayor número o de las clases populares sino garantizar que las clases ricas, nobles y clero no serían vejadas con altos tributos.

Como bien se pude ver, aquel régimen de privilegios y desigualdad, en que las clases ricas no se creían ligadas por el deber de contribuir equitativamente para el sostenimiento del gobierno, no era el más adecuado para la fundación de un sistema de justicia y equidad en el que el más rico paga como más rico, el menos rico como menos rico, y el pobre no paga.

Hacia la mitad del siglo XV, por los años 1435 primero y 1450 después, un ligero bosquejo parecido al INCOME TAX hizo su aparición en Inglaterra, pero sin llegar a tener entonces importancia alguna de significación. Hasta finales del siglo XVIII, en aquel país como en muchos otros, el sistema tributario consistió

\footnotetext{
Fajardo Calderón, Constanza Loreth y Suárez Amaya, Dora Cecilia (2010). Impuesto de renta. Obligaciones Fiscales. Personas naturales - Personas jurídicas. Colombia: Kinesis, pp. 31-35.
} 
casi exclusivamente en derechos de aduanas, impuestos interiores de consumo y gravámenes sobre las propiedades rurales y sobre las sucesiones de colaterales o extraños.

Al comienzo de la formidable lucha que Inglaterra sostuvo contra Napoleón a finales del siglo XVIII y primeros años del XIX en momentos en que las necesidades crecientes e imperiosas de la guerra con tan temible adversario hacia indispensable la constante aprobación de nuevos recursos, los hombres de estado ingleses solo pensaban en obtenerlos de las fuentes fiscales ya conocidas. En efecto, los derechos de aduana se elevaron en proporciones extraordinarias y se establecieron a la vez gravámenes sobre la importación de artículos que antes eran de libre comercio; al tiempo que el sistema de impuestos interiores sobre los objetos de consumo se extendía y complementaba con nuevas imposiciones, gravando todo lo que podía ponerse al alcance de los agentes del fisco: el té, la sal, las bebidas, las drogas, el jabón, las velas, los polvos para el caballo, los relojes, los coches, los caballos, los sirvientes y los perros, entre otros.

En los esfuerzos desesperados por atender a la defensa nacional, no parecía haber impuesto que el gobierno no estableciera y que el pueblo no aceptara. Desde entonces, esta clase de impuesto mostró su ineficiencia para atender a las necesidades del fisco en momentos de supremas y extraordinarias emergencias. Todos aquellos tributos no alcanzaban, ni con mucho, para atender a los gastos más urgentes de la guerra, y de servicio público; el crédito de Inglaterra recaía de manera visible y rápida, al tiempo que el de Francia iba en ascenso. Cada día los consolidados ingleses que se habían mantenido casi a la par hasta 1792 y que en los tres años subsiguientes fluctuaron alrededor de $70 \%$ del precio bajaron hacia el mes de mayo de 1797 a 40\%, al tiempo que el banco de Inglaterra en medio de la universal consternación suspendía los pagos en especie y rehusaba al cambio de sus billetes. Entonces surgieron, como resultado natural de tan angustiosa situación, los proyectos de estadístas y escritores públicos para aumentar las entradas del fisco, y no faltaron quienes propusieran una contribución general y voluntaria para allegar recursos.

Fue entonces cuando habiéndose hecho necesario un llamamiento a la nación para atender a su defensa, surgió en el parlamento inglés un proyecto de contribución directa, que debía ser el primer paso hacia el establecimiento del Income Tax.

En ese sentido, afirman Fino y Vasco (1999, p. 53), Que el primer proyecto fue presentado a la Cámara de los comunes por el ministerio de William Pitt en noviembre de 1797, estableciendo sobre las personas "una serie de gravámenes proporcionados a los recaudos de cada individuo", reconociendo de entrada la equidad tributaria. Una vez aprobado y puesto en práctica dicho impuesto, se encontró que favorecía la evasión debido a la imposibilidad técnica para esta época de confrontar las rentas de las personas.

Para contrarrestar esta situación, en el año siguiente se creó la "presunción de renta" y se fija un impuesto sobre la misma, cualquiera que sea su origen, con esta primera modificación, el impuesto toma el nombre de Income Tax y los resultados fueron muy positivos desde el punto de vista fiscal.

Al concluir la guerra en 1802 y terminar las hostilidades con la paz de Amiens (c. del norte de Francia, capital del Dep. de Somme), el impuesto debía suspenderse. No obstante, el ministro Henry Addington lo restablece al año siguiente con algunas modificaciones relativas a la base que ahora era sobre el patrimonio y sobre las diferentes categorías de rentas y aplicando el concepto de recaudo en la fuente. En 1806 se modifican algunos aspectos y se mantienen hasta 1816, cuando se deroga. Posteriormente se establece en 1842, con carácter transitorio. Se mantiene hasta 1876 cuando se regula en forma definitiva y a partir de esta fecha ha sufrido múltiples reformas pero en esencia se mantiene y es uno de los impuestos más representativos de este sistema tributario.

Colombia y España tienen dentro de sus sistema impositivo el impuesto sobre la renta y para evitar 
la doble imposición y prevenir la evasión fiscal en materia de impuestos sobre la renta y el patrimonio han celebrado un "Convenio" y para su debida interpretación es necesario realizar un análisis comparativo del impuesto sobre la renta en los dos países identificando las similitudes y diferencias.

\section{Tabla 1. Comparación, marco conceptual}

\section{Similitudes}

\section{Colombia}

\section{En su definición}

Impuesto sobre la renta ${ }^{2}$. Es un impuesto directo, que recae sobre los contribuyentes individualmente considerados y grava a quienes en la ley están previstos como sujetos pasivos que hayan percibido ingresos, hecho generador del impuesto susceptible de producir un aumento neto en el patrimonio.

\section{En el mandato constitucional}

Según el Artículo 95 de la Constitución Política de Colombia. Según el Artículo 31 de la Constitución Española de 1978.

\section{En la estructura tributaria}

La relación jurídico-tributaria comprende además de la Se entiende por relación jurídico-tributaria el conjunto de obligación tributaria sustancial, cuyo objeto es el pago del obligaciones y deberes, derechos y potestades originados por tributo, una serie de deberes y obligaciones de tipo formal. la aplicación de los tributos.

\section{Diferencias}

\begin{tabular}{|c|c|}
\hline Colombia & España \\
\hline \multicolumn{2}{|l|}{ 4. En el mandato constitucional } \\
\hline $\begin{array}{l}\text { El presidente de la República como jefe de Estado, jefe del } \\
\text { gobierno y suprema autoridad administrativa: }\end{array}$ & $\begin{array}{l}\text { El jefe de Estado es el rey de España, y un parlamento } \\
\text { bicameral, las cortes generales. }\end{array}$ \\
\hline Colombia es un Estado social de Derecho & España es una monarquía parlamentaria \\
\hline $\begin{array}{l}\text { No está establecida la figura de comunidades autónomas, } \\
\text { la única división establecida es la de los departamentos y } \\
\text { con esta sus respectivos municipios. }\end{array}$ & $\begin{array}{l}\text { España es una nación organizada territorialmente en } 17 \\
\text { comunidades autónomas y } 2 \text { ciudades autónomas. El Título } \\
\text { VIII de la Constitución establece la organización territorial } \\
\text { del Estado en municipios, provincias y comunidades } \\
\text { autónomas, estas con competencias para gestionar sus } \\
\text { propios intereses con un amplio nivel de autonomía, poderes } \\
\text { legislativos, presupuestarios, administrativos y ejecutivos en las } \\
\text { competencias exclusivas que el Estado les garantiza a través de } \\
\text { la Constitución y de cada Estatuto de autonomía. }\end{array}$ \\
\hline \multicolumn{2}{|l|}{ 5. Fuentes del Derecho tributario } \\
\hline $\begin{array}{l}\text { La Constitución Nacional } \\
\text { La ley } \\
\text { Los reglamentos } \\
\text { Los conceptos de la DIAN } \\
\text { Los tratados internacionales } \\
\text { La jurisprudencia y la costumbre }\end{array}$ & $\begin{array}{l}\text { La Constitución } \\
\text { Los tratados o convenios internacionales } \\
\text { Las normas que dicte la Unión Europea y otros organismos } \\
\text { internacionales o supranacionales } \\
\text { Leyes reguladoras de cada tributo y las demás leyes que } \\
\text { contengan disposiciones en materia tributaria } \\
\text { Las disposiciones reglamentarias dictadas en desarrollo de las } \\
\text { normas anteriores }\end{array}$ \\
\hline
\end{tabular}

Guía Legis para la Declaración de Renta. Bogotá D.C. Editorial Legis S.A. 2009. pág. 2.

Manual Práctico de Renta - Agencia Tributaria - Ministerio de Economía y Hacienda pág. 28 


\section{Sujeto activo}

Es el acreedor de la obligación tributaria. El Estado como A los efectos de la ley, la Administración Tributaria estará acreedor del vínculo jurídico queda facultado para exigir integrada por los órganos y entidades de Derecho público que unilateral y obligatoriamente el pago del impuesto, cuando desarrollen las funciones reguladas.

se realiza el hecho generador (está representado por la En el ámbito de competencias del Estado, la aplicación de los Unidad Administrativa Especial - Dirección de Impuesto y tributos, el ejercicio de la potestad sancionadora y la función Aduanas Nacionales, que es sujeto activo de la obligación revisora en vía administrativa corresponde al Ministerio de tributaria).

\section{Sujeto pasivo}

Es el deudor de la obligación tributaria

Economía y Hacienda, en tanto no haya sido expresamente encomendada por ley a otro órgano o entidad de derecho público. Las Comunidades Autónomas y las entidades locales ejercerán las competencias relativas a la aplicación de los tributos y el ejercicio de la potestad sancionadora derivada de dicha aplicación, así como la función revisora en vía administrativa de los actos dictados en el ejercicio de aquellas, con el alcance y en los términos previstos en la normativa que resulte aplicable y su sistema de fuentes.

El Estado y las Comunidades Autónomas y las ciudades con Estatuto de Autonomía podrán suscribir acuerdos de colaboración para la aplicación de los tributos y para el ejercicio de las funciones de revisión en vía administrativa.

Asimismo, podrán establecerse fórmulas de colaboración para la aplicación de los tributos entre las entidades locales, así como entre estas y el Estado o las Comunidades Autónomas.

\section{Hecho generador - hecho imponible}

Es sujeto pasivo el obligado tributario que, según la Ley, debe cumplir la obligación tributaria principal, así como las obligaciones formales inherentes a la misma, sea como contribuyente o como sustituto del mismo.

También se llama hecho imponible, es el presupuesto establecido por la ley para tipificar el tributo y cuya realización origina el nacimiento de la obligación tributaria. Hecho imponible: causa materialmente la obligación. Es un elemento que atribuido al sujeto pasivo, hace parte, total o parcialmente en forma relativa o absoluta, de su capacidad contributiva.

\section{Base gravable}

Valor monetario o unidad de medida del hecho imponible sobre el cual se aplica la tarifa para establecer el valor monetario del crédito fiscal o valor cuantitativo del objeto de la obligación tributaria. Como ejemplo tenemos: en el impuesto sobre la renta la base gravable se obtiene de restar de los ingresos netos totales los costos de producción, las deducciones legales y, por último, las rentas exentas taxativamente señaladas por la ley.

\section{Tarifa}

En materia de impuesto sobre la renta, la ley ha concebido una doble tarifa, según se trate de personas naturales - personas jurídicas. A las primeras se les aplica una tarifa progresiva y a las segundas se les aplica una tarifa proporcional.

\section{Rentas exentas}

Son aquellos ingresos constitutivos de renta que por algunas circunstancias se determinan por la ley, con el fin de lograr la reconstrucción o recuperación de una zona afectada por una grave calamidad, tal como sucede con los beneficios otorgados a las empresas creadas en la zona afectada por la avalancha del río Páez en 1994, o por el terremoto del eje cafetero en 1999.

\section{Hecho imponible - base imponible}

El hecho imponible es el presupuesto fijado por la ley para configurar cada tributo y cuya realización origina el nacimiento de la obligación tributaria principal. La ley podrá completar la delimitación del hecho imponible mediante la mención de supuestos de no sujeción.

Base imponible: cantidad expresiva de una capacidad económica determinada, sobre la que se calcula el pago de los tributos.

\section{Base liquidable}

Resultado de practicar sobre la base imponible las reducciones establecidas por la ley para cada tributo.

\section{Tipo de gravamen}

El tipo de gravamen es la cifra, coeficiente o porcentaje que se aplica a la base liquidable para obtener como resultado la cuota íntegra.

Tipo Impositivo: es la tarifa que se aplica según la calidad del bien o servicio

\section{Exención fiscal}

Consiste en un privilegio conforme a lo establecido por el gobierno o la ley, que excluyen del pago de un impuesto un hecho realizado por un sujeto pasivo, que sin esta exención sí pagaría el impuesto. 


\section{Conclusiones}

1) El impuesto sobre la renta en Colombia y España, en cuanto a su definición tienen una gran similitud, este es un impuesto de carácter directo y personal el cual se fundamenta en los principios tributarios; tiene en cuenta los rendimientos, ganancias y todas las rentas que aumenten el patrimonio del contribuyente.

2) El sujeto activo en Colombia es la DIAN (Dirección de Impuestos y Aduanas Nacionales) y en España es la Agencia Tributaria; estas dos hacen parte del Ministerio de Economía y Hacienda de cada país y el sujeto pasivo aunque en las dos naciones se resume en lo mismo, personas naturales y personas jurídicas, en España se denominarían personas físicas y sociedades, y la obligación de contribuir nace cuando se generan ingresos o se incrementa el patrimonio de acuerdo con las leyes. En Colombia este se Ilama hecho generador, en España el nacimiento de la obligación tributaria principal se denomina hecho imponible y su cálculo expresado en cifras se denomina base imponible.

3) La base gravable en Colombia y la base liquidable en España tienen el mismo significado, las dos son el resultado de descontar a los ingresos, en Colombia los costos, deducciones y las rentas exentas y en España cuando se le restan las reducciones.

4) Tarifa en Colombia o tipo de gravamen en España, son el porcentaje que se le aplica a la base para obtener el valor del impuesto; en España se habla de cifra, coeficiente o tarifa.

5) España es un país formalmente unitario, funciona como una federación descentralizada de comunidades autónomas, cada una de ellas con diferentes niveles de autogobierno que son comunidades autónomas de régimen especial y las comunidades autónomas de régimen común.

\section{Tabla 2. Comparación del impuesto de renta en Colombia y España de las personas naturales (Colombia) - personas físicas (España) y no residentes.}

\section{Similitudes}

\begin{tabular}{l} 
Personas naturales (Colombia) - p \\
$\qquad \begin{array}{l}\text { Colombia } \\
\text { 1. Ámbito de aplicación }\end{array}$ \\
$\begin{array}{l}\text { Todas las personas naturales residentes en Colombia son } \\
\text { contribuyentes del impuesto sobre la renta. }\end{array}$ \\
\hline
\end{tabular}

\section{Sujeto pasivo}

Las personas naturales, nacionales o extranjeras, residentes en el país.

Las personas naturales, nacionales o extranjeras, que no tengan residencia en el país.

La residencia consiste en la permanencia continua en el país por más de seis (6) meses en el año o período gravable, o que se completen dentro de éste; lo mismo que la permanencia discontinua por más de seis meses en el año o período gravable.

Se consideran residentes las personas naturales nacionales que conserven la familia o el asiento principal de sus negocios en el país, aun cuando permanezcan en el exterior.
Todas las personas físicas residentes en España son contribuyentes del impuesto sobre la renta. Teniendo en cuenta los regímenes especiales de Navarra, País Vasco y las especialidades de Ceuta, Melilla e Islas Canarias.

Las personas físicas que tengan su residencia habitual en el territorio español.

Las personas físicas que tuviesen su residencia habitual en el extranjero por alguna circunstancia.

La residencias consiste en la permanencia por más de 183 días, durante el año natural, en territorio español se computarán las ausencias esporádicas, salvo que el contribuyente acredite su residencia fiscal en otro país

Que radique en España el núcleo principal o la base de sus actividades o intereses económicos, de forma directa o indirecta.

El contribuyente tiene su residencia habitual en territorio español cuando, de acuerdo con los criterios anteriores, resida habitualmente en España el cónyuge no separado legalmente y los hijos menores de edad dependan de aquel.

Se consideran contribuyentes las personas de nacionalidad española, su cónyuge no separado legalmente e hijos menores de edad que tuviesen su residencia habitual en territorio extranjero. 


\begin{tabular}{|c|c|}
\hline \multicolumn{2}{|c|}{ Personas naturales (Colombia) - personas físicas (España) No residentes } \\
\hline Colombia & España \\
\hline 3. Hecho imponible (hecho generador) & Base imponible (hecho imponible) \\
\hline Ingresos & Rendimientos \\
\hline $\begin{array}{l}\text { Salarios y demás pagos laborales. } \\
\text { Todas las contraprestaciones y compensaciones tanto } \\
\text { gravadas como no gravadas a título de servicios personales. }\end{array}$ & $\begin{array}{l}\text { Rendimientos del trabajo. } \\
\text { Todas las contraprestaciones o utilidades, cualquiera que sea } \\
\text { su denominación o naturaleza, dinerarias o en especie, que } \\
\text { deriven, directa o indirectamente, del trabajo personal o de la } \\
\text { relación laboral o estatutaria. }\end{array}$ \\
\hline $\begin{array}{l}\text { Ingresos por arrendamiento de inmuebles, contienen los } \\
\text { arrendamientos de locales, casas, oficinas y en general de } \\
\text { cualquier inmueble. }\end{array}$ & $\begin{array}{l}\text { Rendimientos de capital inmobiliario, contiene los } \\
\text { arrendamientos de bienes inmuebles rústicos y urbanos, en } \\
\text { general de cualquier bien inmueble. }\end{array}$ \\
\hline Rentas exentas & Rentas exentas \\
\hline $\begin{array}{l}\text { Lo recibido por gastos de entierro del trabajador. } \\
\text { El seguro por muerte, y las compensaciones por muerte } \\
\text { de los miembros de las Fuerzas Militares y de la Policía } \\
\text { Nacional. }\end{array}$ & $\begin{array}{l}\text { Las prestaciones percibidas por entierro o sepelio, con el límite } \\
\text { del importe total de los gastos incurridos. }\end{array}$ \\
\hline Valor de los ingresos en especie. & Valor de las rentas en especie \\
\hline Deducciones & Reducciones \\
\hline $\begin{array}{l}\text { Gastos de reparación y conservación de inmuebles y } \\
\text { activos fijos. }\end{array}$ & Gastos de reparación y conservación \\
\hline $\begin{array}{l}\text { Los intereses que se paguen sobre préstamos para } \\
\text { adquisición de vivienda del contribuyente. } \\
\text { Deducción de costos financieros en leasing habitacional } \\
\text { siempre que el leasing tenga por objeto un bien inmueble } \\
\text { destinado a vivienda. }\end{array}$ & $\begin{array}{l}\text { Deducción (descuento). } \\
\text { Deducción por inversión en vivienda habitual. Los } \\
\text { contribuyentes podrán deducirse el } 7,5 \% \text { de las cantidades } \\
\text { satisfechas en el período de que se trate por la adquisición o } \\
\text { rehabilitación de la vivienda que constituya o vaya a constituir } \\
\text { la residencia habitual del contribuyente. }\end{array}$ \\
\hline $\begin{array}{l}\text { Deducción por inversiones en activos fijos reales y } \\
\text { productivos. (Derogada por la ley } 1430 \text { de } 2010) \text {. } \\
\text { Deducción por inversiones en nuevas plantaciones, riesgos, } \\
\text { pozos y silos. } \\
\text { Deducción por inversiones en desarrollo científico y } \\
\text { tecnológico. } \\
\text { Deducción por amortización en el sector agropecuario. }\end{array}$ & $\begin{array}{l}\text { Deducción (descuento) } \\
\text { A los contribuyentes por este impuesto que ejerzan actividades } \\
\text { económicas les serán de aplicación los incentivos y estímulos a } \\
\text { la inversión empresarial. }\end{array}$ \\
\hline Deducción por donaciones & $\begin{array}{l}\text { Deducción (descuento) } \\
\text { Deducciones por donativos. }\end{array}$ \\
\hline $\begin{array}{l}\text { El valor a cargo del trabajador en los aportes obligatorios } \\
\text { al Sistema General de Seguridad Social en Salud es } \\
\text { deducible. }\end{array}$ & $\begin{array}{l}\text { Las aportaciones realizadas por los trabajadores a los planes } \\
\text { de previsión social empresarial. }\end{array}$ \\
\hline Deducción de pagos por salud y educación. & $\begin{array}{l}\text { Las aportaciones y contribuciones a mutualidades de previsión } \\
\text { social. }\end{array}$ \\
\hline
\end{tabular}

\section{Conclusiones}

1) En el territorio español se ha dividido el impuesto sobre la renta en: impuesto sobre la renta de las personas físicas, impuesto sobre sociedades e impuesto sobre residentes; cada división presenta sus reglas, es decir, que las personas físicas no tendrán las mismas reducciones de las sociedades, ni los mismos hechos imponibles, las personas físicas, las sociedades y los no residentes se rigen cada uno por una ley distinta. En Colombia hablamos de personas naturales y personas jurídicas, comprendidas en las mismas leyes.

2) Los ingresos o rendimientos son la base del impuesto, en Colombia podemos distinguir varios como los salarios y demás pagos laborales, los servicios personales como los honorarios, arrendamientos, etc. En España se denominan rendimientos y se clasifican en 
rendimientos del trabajo y rendimientos del capital inmobiliario. Tanto en Colombia como en España se tienen establecidas como renta exenta lo recibido por entierro del trabajador, seguro de muerte y compensaciones recibidas por este.

3) Las reducciones y deducciones, que son los valores que se restan a los ingresos para obtener la base gravable, difieren para cada país, encontrando que en Colombia se deduce $100 \%$ de la tarifa del impuesto de industria y comercio, avisos y tableros y predial cuando el gasto tenga relación de causalidad con la actividad productora de renta; en España, en cambio, se puede reducir cualquier impuesto o tasa no estatal, siempre que tenga relación con la actividad productora de renta; aquí no hay exclusión, abarca todos los impuestos estatales.

En Colombia solo se pueden deducir los intereses que se paguen sobre los préstamos para adquisición de vivienda; en España, en cambio, se trata como descuento y se puede reducir no los intereses sino las cuotas que se paguen en $7.5 \%$.

La deducción por inversión en activos fijos en Colombia fue derogada en la reforma tributaria para el año 2010, por la ley 1430 de 2010, siguen vigentes las deducciones por inversión en nuevas plantaciones, inversiones en desarrollo científico, deducción por amortización en el sector agropecuario; en España se trata como descuento aquellas inversiones empresariales con la condición de que el contribuyente ejerza actividades económicas, no hay una exclusión en cuanto al sector en el que se hagan estas inversiones, como sí lo hay en Colombia.

Las donaciones son parte importante en las deducciones que se tienen establecidas en Colombia, existiendo distintas tarifas y dependiendo de la entidad a quien se efectúa la donación; en España también existe esta figura pero se presenta como un descuento.

Los aportes obligatorios a la salud del trabajador son deducibles tanto en nuestro país como en España.

\section{Diferencias}

\section{Personas naturales (Colombia) - Personas físicas (España). No residentes}

Colombia

España

\section{En sus elementos}

Elementos del impuesto de renta en Colombia

1. Sujeto activo

2. Ssujeto pasivo

3. Hecho imponible (hecho generador)

4. Base gravable 5. Tarifa

6. Descuento

Elementos del impuesto de renta en España

1. Sujeto activo

2. Sujeto pasivo

3. Base imponible (hecho imponible)

4. Base liquidable 5. Tipo de gravamen

6. Cuota tributaria

7. Deuda tributaria

Sujeto activo

Dirección de Impuestos y Aduanas Nacionales (DIAN)

Agencia tributaria

\section{Sujeto pasivo}

Persona natural

Persona física

En Colombia tributa la persona natural de manera individual.

En España tiene la opción de tributar individual o conjuntamente (tributación familiar).

Se consideran residentes las personas naturales nacionales Se consideran contribuyentes las personas de nacionalidad que conserven la familia o el asiento principal de sus española, su cónyuge no separado legalmente e hijos menores negocios en el país, aun cuando permanezcan en el de edad que tuviesen su residencia habitual en territorio exterior.

No específica qué clase de contribuyentes. extranjero; miembros de misiones diplomáticas españolas, miembros de las oficinas consulares españolas, etc.

Todo el territorio colombiano tiene el mismo tratamiento, Los contribuyentes con residencia habitual en el territorio no hay comunidades autónomas ni ciudades con estatuto español son residentes en el territorio de una comunidad de autonomía. 


\section{Personas naturales (Colombia) - Personas físicas (España). No residentes}

$$
\text { Colombia }
$$

Para saber quién está obligado a declarar, todo depende Para saber quién está obligado a declarar, todo depende del de que superen los montos por ingresos y patrimonio al monto de sus ingresos al 31 de diciembre del año gravable, 31 de diciembre del año gravable, que realicen pagos las deducciones y su procedencia. (Lo dicho anteriormente que superen los montos establecidos para compras con para todos aquellos quienes se clasifican como no declarantes tarjetas de crédito, superen los montos en consignaciones, pero que en algún momento si no cumplen los requisitos etc. (lo dicho anteriormente para todos aquellos quienes mencionados anteriormente pueden llegar a serlo.

se clasifican como no declarantes pero que en algún momento si no cumplen los requisitos mencionados anteriormente pueden llegar a serlo.

En Colombia están obligados a declarar quienes superen En España, están obligados a declarar todas las personas los montos mencionados anteriormente, las personas del con derecho a deducciones por inversión en vivienda, régimen común, los usuarios aduaneros y en general cuenta ahorro-empresa doble imposición internacional o quienes cumplan con la obligación formal.

que hayan realizado aportaciones a patrimonios protegidos Las deducciones no se dan con anterioridad a las de las personas con discapacidad, planes de pensiones, declaraciones, solo al momento de declarar, se sabe qué planes de previsión asegurados o mutualidades de previsión tipo de deducción pueden aplicar los contribuyentes. social, planes de previsión social empresarial y seguros de dependencia que reduzcan la base imponible, cuando ejerciten tal derecho durante el pasado año y quienes hayan disfrutado de las deducciones por maternidad y nacimiento o adopción.

Residencia Residencia

En Colombia la residencia se asimila a las personas naturales.

El domicilio se asimila a las personas jurídicas.

\section{Hecho imponible (hecho generador)}

En España la residencia se asimila a las personas físicas y los establecimientos permanentes de las personas físicas.

Base gravable

Depuración

Clases de renta

Renta líquida gravable

Renta presuntiva

Renta por comparación patrimonial

Ingreso

Clasificación del ingreso

Ingreso operacional

No operacional

\section{Base imponible (hecho imponible)}

Base liquidable general

Base liquidable del ahorro

Depuración

Clases de renta

Renta general

Renta del ahorro

Rendimiento

Clasificación del rendimiento

Los rendimientos de trabajo

Los rendimientos de capital

Los rendimientos de actividades económicas.

Las ganancias y pérdidas patrimoniales.

Las imputaciones de renta que se establezcan por ley.

Valor de los ingresos en especie.

Rendimientos del trabajo en especie

Si en pago de obligaciones pactadas en dinero se dieren especies, el valor de estas se determina, salvo prueba en contrario, por el precio fijado en el contrato.

Constituyen rendimientos del trabajo en especie la utilización, consumo u obtención, para fines particulares, de bienes, derechos o servicios de forma gratuita o por precio inferior al normal de mercado

Los salarios y demás ingresos laborales se clasifican Los rendimientos del trabajo reúnen todo lo que tiene que de manera individual a los ingresos por honorarios, comisiones y servicios.

ver con pagos por salar

Prestaciones por desempleo

Ingresos por arrendamiento inmuebles e ingreso por Rendimiento de capital y los rendimientos de capital mobiliario, arrendamiento de bienes muebles, está conformado por los arrendamientos de maquinarias, activos fijos, etc. está conformado por dividendos de acciones, intereses de cuentas, rendimientos de activos, primas por emisión de acciones, arrendamiento de bienes muebles, etc.

Ingresos por honorarios, comisiones y servicios.

Rendimientos de actividades económicas, contiene los ingresos por ejercicio de profesiones liberales, por prestaciones de servicios, incluidas las artesanías, agrícolas, forestales, mineras y deportivas. 


\begin{tabular}{|c|c|}
\hline \multicolumn{2}{|c|}{ Personas naturales (Colombia) - Personas físicas (España). No residentes } \\
\hline Colombia & España \\
\hline Intereses y rendimiento financieros & Rendimientos de capital mobiliario \\
\hline Venta activos fijos & Rendimientos de capital mobiliario \\
\hline Contratos de fiducia mercantil & Rendimientos de capital mobiliario \\
\hline Ingresos no constitutivos de renta & $\begin{array}{l}\text { No hay establecidos en la ley española, los ingresos no } \\
\text { constitutivos de renta }\end{array}$ \\
\hline \multicolumn{2}{|l|}{ Rentas exentas } \\
\hline $\begin{array}{l}\text { Las indemnizaciones por accidente de trabajo o } \\
\text { enfermedad. } \\
\text { Las indemnizaciones que impliquen protección a la } \\
\text { maternidad. } \\
\text { El auxilio de cesantía y los intereses sobre cesantías. } \\
\text { Las pensiones de jubilación, invalidez, vejez, de } \\
\text { sobrevivientes y sobre riesgos profesionales. } \\
\text { El seguro por muerte, y las compensaciones por muerte } \\
\text { de los miembros de las Fuerzas Militares y de la Policía } \\
\text { Nacional. } \\
\text { El porcentaje exento del salario considerado como gastos } \\
\text { de representación de los magistrados, de los tribunales y } \\
\text { sus fiscales, jueces de la República, profesores y rectores } \\
\text { de universidades públicas } \\
\text { El exceso del salario básico percibido por los oficiales y } \\
\text { suboficiales de las Fuerzas Militares y de la Policía Nacional } \\
\text { y de los agentes de esta última. } \\
\text { Indemnizaciones por seguros de vida }\end{array}$ & $\begin{array}{l}\text { Las pensiones por inutilidad o incapacidad permanente del } \\
\text { régimen de clases pasivas, siempre que la lesión o enfermedad } \\
\text { que hubiera sido causa de aquéllas inhabilitara por completo } \\
\text { al perceptor de la pensión para toda profesión u oficio. } \\
\text { Las pensiones reconocidas en favor de aquellas personas } \\
\text { que sufrieron lesiones o mutilaciones con ocasión o como } \\
\text { consecuencia de la guerra civil. } \\
\text { Las prestaciones públicas extraordinarias por actos de terrorismo } \\
\text { y las pensiones derivadas de medallas y condecoraciones } \\
\text { concedidas por actos de terrorismo. } \\
\text { Las ayudas económicas reguladas en el artículo } 2 \text { de la ley } \\
14 / 2002 \text {, de } 5 \text { de junio. que dice: } \\
\text { Ayudas sociales. } \\
\text { Los beneficiarios tendrán derecho a percibir una ayuda } \\
\text { económica, por una sola vez, a tanto alzado, por importe de } \\
18.030,36 \text { euros (equivalentes a } 3.000 .000 \text { de pesetas). La } \\
\text { percepción de esta ayuda será compatible con la de cualquier } \\
\text { pensión pública que el beneficiario tuviera derecho a percibir. } \\
\text { Rendimientos procedentes de operaciones de capitalización, de } \\
\text { contratos de seguro de vida o invalidez y de rentas derivadas } \\
\text { de la imposición de capitales. } \\
\text { Las indemnizaciones por despido o cese del trabajador. } \\
\text { Las ayudas de cualquier clase percibidas por los afectados por } \\
\text { el virus de inmunodeficiencia humana. } \\
\text { Las ayudas de cualquier clase percibidas por los afectados por } \\
\text { el virus de inmunodeficiencia humana } \\
\text { Becas públicas y las becas concedidas por las entidades sin } \\
\text { fines lucrativos } \\
\text { Las anualidades por alimentos percibidas de los padres en } \\
\text { virtud de decisión judicial. }\end{array}$ \\
\hline $\begin{array}{l}\text { Ingresos no constitutivos de renta } \\
\text { Los premios y distinciones obtenidos en concursos o } \\
\text { certámenes nacionales e internacionales de carácter } \\
\text { científico, literario, periodístico, artístico y deportivo, } \\
\text { reconocidos por el gobierno nacional. }\end{array}$ & $\begin{array}{l}\text { Rentas exentas } \\
\text { Los premios literarios, artísticos o científicos, el Premio Príncipe } \\
\text { de Asturias, en sus distintas modalidades, otorgados por la } \\
\text { Fundación Príncipe de Asturias. }\end{array}$ \\
\hline Ingreso no constitutivo de renta & Rendimiento de capital mobiliario \\
\hline $\begin{array}{l}\text { La utilidad en enajenación de acciones } \\
\text { La distribución de utilidades en acciones o cuotas de } \\
\text { interés social, o su traslado a la cuenta de capital }\end{array}$ & $\begin{array}{l}\text { La utilidad, procedente de una entidad por la condición de } \\
\text { socio, accionista, asociado o partícipe. }\end{array}$ \\
\hline $\begin{array}{l}\text { Ingreso no constitutivo de renta } \\
\text { El componente inflacionario de los rendimientos financieros } \\
\text { y el componente inflacionario de los rendimientos } \\
\text { financieros que distribuyan los fondos de inversión, mutuos } \\
\text { de inversión y de valores }\end{array}$ & No se encuentra establecida en la ley española. \\
\hline $\begin{array}{l}\text { Ingreso no constitutivo de renta } \\
\text { Recompensas }\end{array}$ & $\begin{array}{l}\text { Rentas exentas } \\
\text { Las prestaciones públicas extraordinarias por actos de terrorismo }\end{array}$ \\
\hline $\begin{array}{l}\text { Ingreso no constitutivo de renta } \\
\text { Utilidad en la venta de casa o apartamento de habitación }\end{array}$ & $\begin{array}{l}\text { Rentas exentas } \\
\text { Rendimientos de capital mobiliario }\end{array}$ \\
\hline
\end{tabular}




\section{Personas naturales (Colombia) - Personas físicas (España). No residentes}

$$
\text { Colombia }
$$

\section{España}

Ingresos no constitutivos de renta

Las indemnizaciones por seguros de daño emergente

Ingresos

Participaciones y dividendos

Ingresos no constitutivos de renta

Indemnizaciones por destrucción o renovación de cultivos, y por control de plagas

Los gananciales

Las primas de localización y vivienda

la distribución de utilidades por liquidación

Los subsidios y ayudas otorgadas por el gobierno nacional en el programa Agro Ingreso Seguro

Aportes del empleador al fondo de cesantías

Incentivo al ahorro de largo plazo para el fomento de la construcción

Ingresos no constitutivos de renta

Donaciones para partidos, movimientos y campañas políticas

Ingresos no constitutivos de renta

Aportes a los fondos de pensiones y pagos de las pensiones no constituyen renta ni ganancia ocasional para el beneficiario o participe de los fondos de pensiones de jubilación o invalidez, el aporte del patrocinador o empleador del afiliado al fondo.

Ingresos no constitutivos de renta

Para el ganadero, el valor de sus terneros nacidos y enajenados dentro del mismo año gravable.
Rentas exentas

Las indemnizaciones como consecuencia de responsabilidad civil por daños personales

Rentas exentas

Los dividendos y participaciones

No se encuentra establecida en la ley española.
Reducción

Reducción por cuotas y aportaciones a partidos políticos.

Rendimientos del trabajo

Las contribuciones o aportaciones satisfechas por los empresarios para hacer frente a los compromisos por pensiones en los términos previstos por la ley.

Rendimientos de actividades económicas

Se considerarán rendimientos íntegros de actividades económicas aquellos que, procediendo del trabajo personal y del capital conjuntamente, o de uno solo de estos factores, supongan por parte del contribuyente la ordenación por cuenta propia de medios de producción y de recursos humanos o de uno de ambos, con la finalidad de intervenir en la producción o distribución de bienes o servicios.

En particular, tienen esta consideración los rendimientos de las actividades ganaderas.

Ingreso no constitutivo de renta

Rendimientos de capital mobiliario

Las sumas que distribuyan 0 abonen en cuanta a sus afiliados en la parte que provenga de dividendos, valorización de acciones o bonos convertibles en acciones y utilidades recibidas en la enajenación de acciones y bonos convertibles en acciones.

Ingreso no constitutivo de renta

El valor fiscal por el cual se reciben los dividendos o Los dividendos y participaciones en beneficios con el límite de participaciones en acciones o cuotas de interés social, 1.500 euros anuales.

provenientes de la distribución de utilidades o reservas que sean susceptibles de distribuirse como no gravadas, es el valor de las utilidades o reservas distribuidas.

Esta establecido en el impuesto de renta en Colombia la No está establecida en el impuesto de renta en España la figura figura del costo.

No se encuentran establecidas cuáles son las clases de Se establecen en la ley ganancias y pérdidas patrimoniales. ganancias y pérdidas patrimoniales en cuanto al impuesto sobre la renta en la ley colombiana, simplemente qué bienes o posesiones integran el patrimonio.

Toda ganancia y pérdida altera el patrimonio.

Patrimonio

-Utilidad (ingreso)

-Perdida (deducción)

Que se calculan según las características de cada activo.
Rentas exentas de costo.

作

de socio, accionista, asociado o partícipe.

Hay ganancias y pérdidas que no alteran el patrimonio.

Pérdidas y ganancias patrimoniales

- Importe (valor) de las ganancias o pérdidas patrimoniales, que se calcula según las normas específicas de valoración. 


\begin{tabular}{|c|}
\hline Personas naturales (Colombia) - Pe \\
\hline Colombia \\
\hline $\begin{array}{l}\text { Patrimonio } \\
\text { Valor patrimonial de los activos }\end{array}$ \\
\hline $\begin{array}{l}\text { Aumento patrimonial no justificado, se calcula la renta por } \\
\text { comparación patrimonial que consiste, cuando la suma } \\
\text { de la renta gravable, las rentas exentas y la ganancia } \\
\text { ocasional neta, resultare inferior a la diferencia entre } \\
\text { el patrimonio líquido del último período gravable y el } \\
\text { patrimonio líquido del período inmediatamente anterior, } \\
\text { dicha diferencia se considera renta gravable, a menos que } \\
\text { el contribuyente demuestre que el aumento patrimonial } \\
\text { obedece a causas justificativas. }\end{array}$ \\
\hline
\end{tabular}

En Colombia, los no residentes obligados a declarar lo hacen de la misma manera que las personas naturales obligadas a declarar.

En España, los no residentes, obligados a declarar, su base imponible es un poco distinta de la base imponible de las personas físicas obligadas a declarar, ya que la ley especifica unas rentas específicas, como, por ejemplo, las obtenidas en establecimientos permanentes.

\begin{tabular}{l|l} 
Deducciones & Reducciones
\end{tabular}

No se encuentra establecida en la ley colombiana.

Reducciones de determinados rendimientos de trabajo

El $40 \%$ de reducción, en el caso de rendimientos íntegros distintos de los previstos en el artículo 17.2.a de la Ley 35 de 2006, de 28 de noviembre, que tengan un período de generación superior a dos años y que no se obtengan de forma periódica o recurrente, así como aquellos que se califiquen reglamentariamente como obtenidos de forma notoriamente irregular en el tiempo.

El $40 \%$ de reducción, en el caso de las prestaciones establecidas en el artículo 17.2.a. 1 y 2 de la Ley 35 de 2006, del 28 de noviembre, que se perciban en forma de capital, siempre que hayan transcurrido más de dos años desde la primera aportación.

El plazo de dos años no resultará exigible en el caso de prestaciones por invalidez.

Las reducciones previstas en este artículo no se aplicarán a las contribuciones empresariales imputadas que reduzcan la base imponible, de acuerdo con lo dispuesto en los artículos 51, 53 y en la disposición adicional undécima de la Ley 35 de 2006, de 28 de noviembre.

No se encuentra establecida en la ley colombiana.

Reducción por obtención de rendimientos de trabajo

El rendimiento neto del trabajo se minorará en las siguientes cuantías:

Contribuyentes con rendimientos netos del trabajo iguales o inferiores a 9.180 euros: 4.080 euros anuales.

Contribuyentes con rendimientos netos del trabajo comprendidos entre $9.180,01$ y 13.260 euros: 4.080 euros menos el resultado de multiplicar por 0,35 la diferencia entre el rendimiento del trabajo y 9.180 euros anuales.

Contribuyentes con rendimientos netos del trabajo superior a 13.260 euros o con rentas, excluidas las exentas, distintas de las de los trabajos superiores a 6.500 euros: 2.652 euros anuales.

Se incrementará en $100 \%$ el importe de la reducción prevista en el apartado 1 de este artículo, en los siguientes supuestos: Trabajadores activos mayores de 65 años que continúen - prolonguen la actividad laboral, en las condiciones que reglamentariamente se determinen. 


\begin{tabular}{|c|c|}
\hline \multicolumn{2}{|c|}{ Personas naturales (Colombia) - Personas físicas (España). No residentes } \\
\hline Colombia & España \\
\hline No se encuentra establecida en la ley colombiana. & $\begin{array}{l}\text { Se incrementará en } 100 \% \text { el importe de la reducción prevista } \\
\text { en el apartado } 1 \text { de este artículo, en los siguientes supuestos: } \\
\text { Trabajadores activos mayores de } 65 \text { años que continúen } \\
\text { o prolonguen la actividad laboral, en las condiciones que } \\
\text { reglamentariamente se determinen. } \\
\text { Contribuyentes desempleados inscritos en la oficina de empleo } \\
\text { que acepten un puesto de trabajo que exija el traslado de su } \\
\text { residencia habitual a un nuevo municipio, en las condiciones } \\
\text { que reglamentariamente se determinen. Este incremento se } \\
\text { aplicará en el periodo impositivo en el que se produzca el } \\
\text { cambio de residencia y en el siguiente. } \\
\text { Adicionalmente, las personas con discapacidad que obtengan } \\
\text { rendimientos del trabajo como trabajadores activos podrán } \\
\text { minorar el rendimiento neto del trabajo en } 3.264 \text { euros anuales. } \\
\text { Dicha reducción será de } 7.242 \text { euros anuales, para las personas } \\
\text { con discapacidad que siendo trabajadores activos acrediten } \\
\text { necesitar ayuda de terceras personas o movilidad reducida, o un } \\
\text { grado de minusvalía igual o superior a } 65 \% \text {. } \\
\text { Como consecuencia de la aplicación de las reducciones previstas } \\
\text { en este artículo, el saldo resultante no podrá ser negativo. }\end{array}$ \\
\hline No se encuentra establecida en la ley colombiana. & $\begin{array}{l}\text { Reducción de rendimientos de capital inmobiliario } \\
\text { Los saldos de dudoso cobro en las condiciones que se } \\
\text { establezcan reglamentariamente. } \\
\text { Las cantidades devengadas por terceros como consecuencia } \\
\text { de servicios personales. } \\
\text { Las cantidades destinadas a la amortización del inmueble } \\
\text { y de los demás bienes cedidos con este, siempre que } \\
\text { respondan a su depreciación efectiva, en las condiciones que } \\
\text { reglamentariamente se determinen. } \\
\text { Los rendimientos netos con un período de generación superior } \\
\text { a dos años, así como los que se califiquen reglamentariamente } \\
\text { como obtenidos de forma notoriamente irregular en el tiempo, } \\
\text { se reducirán en } 40 \% \text {. }\end{array}$ \\
\hline No se encuentra establecida en la ley colombiana. & $\begin{array}{l}\text { Reducciones de rendimientos de capital mobiliario. } \\
\text { Los gastos de administración y depósito de valores negociables. } \\
\text { A estos efectos, se considerarán como gastos de administración } \\
\text { y depósito aquellos importes que repercutan las empresas de } \\
\text { servicios de inversión, entidades de crédito u otras entidades } \\
\text { financieras. } \\
\text { Cuando se trate de rendimientos derivados de la prestación } \\
\text { de asistencia técnica, del arrendamiento de bienes muebles, } \\
\text { negocios o minas o de subarrendamientos, se deducirán de los } \\
\text { rendimientos íntegros los gastos necesarios para su obtención } \\
\text { y, en su caso, el importe del deterioro sufrido por los bienes o } \\
\text { derechos de que los ingresos procedan. }\end{array}$ \\
\hline No se encuentra establecida en la ley colombiana. & $\begin{array}{l}\text { Reducciones de rendimientos de actividades económicas. } \\
\text { Los rendimientos netos con un período de generación } \\
\text { superior a dos años, así como aquéllos que se califiquen } \\
\text { reglamentariamente como obtenidos de forma notoriamente } \\
\text { irregular en el tiempo, se reducirán en } 40 \% \text {. }\end{array}$ \\
\hline $\begin{array}{l}\text { Deducción de intereses } \\
\text { Por honorarios, comisiones y servicios. } \\
\text { Deducción por salarios. } \\
\text { Deducción en el negocio de la ganadería. } \\
\text { Deducción de los aportes pensionales que voluntariamente } \\
\text { haga el trabajador independiente. } \\
\text { Incentivo al ahorro de largo plazo para el fomento de la } \\
\text { construcción. }\end{array}$ & No se encuentra establecida en la ley española. \\
\hline
\end{tabular}




\begin{tabular}{|c|c|}
\hline \multicolumn{2}{|c|}{ Personas naturales (Colombia) - Personas físicas (España). No residentes } \\
\hline Colombia & España \\
\hline Deducción por pagos de educación & $\begin{array}{l}\text { Las cotizaciones a los colegios de huérfanos o entidades similares. } \\
\text { Las cuotas satisfechas a sindicatos y colegios profesionales, } \\
\text { cuando la colegiación tenga carácter obligatorio. }\end{array}$ \\
\hline No se encuentra establecida en la ley colombiana. & Las primas satisfechas a los planes de previsión asegurados. \\
\hline No se encuentra establecida en la ley colombiana. & $\begin{array}{l}\text { Las primas satisfechas a los seguros privados que cubran exclusiva- } \\
\text { mente el riesgo de dependencia severa o de gran dependencia }\end{array}$ \\
\hline $\begin{array}{l}\text { Deducciones - persona jurídica } \\
\text { Los patronos pueden deducir por concepto de pensiones } \\
\text { de jubilación e invalidez de los trabajadores: } \\
\text { Los pagos efectivamente efectuados } \\
\text { Las cuotas o aportes efectivamente pagados. }\end{array}$ & $\begin{array}{l}\text { Reducción - persona física } \\
\text { Aportaciones y contribuciones a planes de pensiones. }\end{array}$ \\
\hline No se encuentra establecida en la ley colombiana. & $\begin{array}{l}\text { Las aportaciones realizadas a planes de pensiones a favor de } \\
\text { personas con discapacidad con un grado de minusvalía física } \\
\text { o sensorial igual o superior a } 65 \% \text {, psíquica igual o superior } \\
\text { a } 33 \% \text {, así como de personas que tengan una incapacidad } \\
\text { declarada judicialmente con independencia de su grado }\end{array}$ \\
\hline No se encuentra establecida en la ley colombiana. & $\begin{array}{l}\text { Aportaciones a patrimonios protegidos de las personas con } \\
\text { discapacidad. }\end{array}$ \\
\hline No se encuentra establecida en la ley colombiana. & $\begin{array}{l}\text { Las pensiones compensatorias a favor del cónyuge y las } \\
\text { anualidades por alimentos, con excepción de las fijadas en } \\
\text { favor de los hijos del contribuyente, satisfechas ambas por } \\
\text { decisión judicial, podrán ser objeto de reducción en la base } \\
\text { imponible. }\end{array}$ \\
\hline $\begin{array}{l}\text { Deducción } \\
\text { Los contribuyentes podrán deducir los gastos efectuados } \\
\text { en el exterior, que tengan relación de causalidad con } \\
\text { rentas de fuente dentro del país, siempre y cuando se haya } \\
\text { efectuado la retención en la fuente si lo pagado constituye } \\
\text { para su beneficiario renta gravable en Colombia. }\end{array}$ & $\begin{array}{l}\text { Deducción (descuento) } \\
\text { Cuando entre las rentas del contribuyente figuren rendimientos } \\
\text { o ganancias patrimoniales obtenidos y gravados en el } \\
\text { extranjero, se deducirá la menor de las cantidades siguientes: } \\
\text { El importe efectivo de lo satisfecho en el extranjero por razón de } \\
\text { un impuesto de naturaleza idéntica o análoga a este impuesto } \\
\text { o al Impuesto sobre la Renta de no Residentes sobre dichos } \\
\text { rendimientos o ganancias patrimoniales. } \\
\text { El resultado de aplicar el tipo medio efectivo de gravamen a la } \\
\text { parte de base liquidable gravada en el extranjero. }\end{array}$ \\
\hline No se encuentra establecida en la ley colombiana. & $\begin{array}{l}\text { Deducción (descuento) } \\
\text { Deducción por maternidad. }\end{array}$ \\
\hline Renta presuntiva & No se encuentra establecido en la ley española \\
\hline Renta por comparación patrimonial & No se encuentra establecido en la ley española \\
\hline No se encuentra establecida en la ley colombiana. & $\begin{array}{l}\text { Adecuación del impuesto a las circunstancias personales y } \\
\text { familiares } \\
\text { Mínimo personal y familiar } \\
\text { Mínimo del contribuyente } \\
\text { Mínimo por descendiente } \\
\text { Mínimo por ascendientes } \\
\text { Mínimo por discapacidad }\end{array}$ \\
\hline 18. Impuesto sobre la renta líquida gravable & Cuota tributaria \\
\hline $\begin{array}{l}\text { Determinación del impuesto } \\
\text { Se calcula un impuesto. } \\
\text { Mediante la aplicación de la tarifa a la renta líquida } \\
\text { gravable, según la tabla para el impuesto de las personas } \\
\text { naturales. } \\
\text { El impuesto que se genera se destina en su totalidad al } \\
\text { Estado, no destinan porcentajes o cuotas al departamento } \\
\text { donde pertenezca el contribuyente. }\end{array}$ & $\begin{array}{l}\text { Determinación del impuesto } \\
\text { Se calcula el impuesto estatal y el gravamen autonómico. } \\
\text { La cuota íntegra estatal, es la parte del impuesto a pagar que } \\
\text { se destina para el estado en general, es decir, para España. } \\
\text { La cuota íntegra autonómica es la parte del impuesto a pagar, } \\
\text { que se destina a la comunidad autónoma a la que pertenezca } \\
\text { el declarante. } \\
\text { Cuota íntegra estatal } \\
\text { A las bases liquidables y del ahorro, se les aplica la escala } \\
\text { general del impuesto y los tipos de gravamen del ahorro. }\end{array}$ \\
\hline
\end{tabular}




\section{Personas naturales (Colombia) - Personas físicas (España). No residentes}

$$
\text { Colombia }
$$

\section{España}

\section{Tarifa}

La tarifa para personas naturales se clasifica: Tarifa para personas naturales y extranjeras residentes y para obtener la cuota íntegra. asignación y donaciones modales.

Las personas naturales establecen el impuesto aplicando una tabla, siguiendo el procedimiento establecido en esta.

No se encuentra establecida en la ley colombiana.

\section{Escala del impuesto}

La escala de las personas físicas se clasifica:

Escala general del impuesto.

Escala autonómica o complementaria

Para los no residentes obligados a declarar, aplica la misma tabla del impuesto de las personas naturales.

\section{Descuentos tributarios}

Por inversiones en acciones de sociedades agropecuarias Por reforestación

Por impuestos pagados en el exterior Impuesto sobre las ventas en la Importación de maquinaria pesada para industrias básicas distintas de las de las personas físicas, y unas tarifas iguales a la de las sociedades. Ej.: 35\% y 40\%. Para actividades iguales.

\section{Deducciones}

Deducción por inversión en vivienda habitual

Deducción en actividades económicas

Deducción por donativos

Deducción por rentas obtenidas en Ceuta y Melilla.

Deducción por actuaciones para la protección y difusión del Patrimonio Histórico Español y de las ciudades, conjuntos y bienes declarados Patrimonio Mundial

Deducción por cuanta de ahorro-empresa.

No se encuentra establecida en la ley colombiana.

Gravamen autonómico

(Cuota íntegra autonómica)

No se encuentra establecida en la ley colombiana.

Se determina después de haber establecido la cuota líquida estatal.

A la base liquidable general y del ahorro se le aplica la escala autonómica o complementaria del impuesto y el tipo de gravamen del ahorro.

No se encuentra establecida en la ley colombiana.

Cuota líquida autonómica

La cuota líquida autonómica se determina restando la deducción por inversión en vivienda habitual.

Impuesto sobre la renta líquida gravable menos:

Anticipos de renta por el año gravable 2010.

Total retenciones año gravable 2010.

Anticipo renta por el año gravable 2011.

\section{Cuota diferencial}

Es la suma de la cuota líquida estatal y autonómica, menos: La deducción por doble imposición internacional La deducción por obtención de rendimientos del trabajo o de actividades económicas.

Las deducciones a que se refieren el artículo 91.8 y el artículo 92.4 de la Ley 35 de 2006, de 28 de noviembre.

Cuando el contribuyente adquiera su condición por cambio de residencia, las retenciones e ingresos a cuenta a que se refiere el apartado 8 del artículo 99 de la Ley 35 de 2006, de 28 de noviembre, así como las cuotas satisfechas del Impuesto sobre la Renta de no Residentes y devengadas durante el período impositivo en que se produzca el cambio de residencia.

Las retenciones a que se refiere el apartado 11 del artículo 99 de la Ley 35 de 2006, de 28 de noviembre.

Las retenciones, los ingresos a cuenta y los pagos fraccionados previstos en la Ley 35 de 2006, de 28 de noviembre y en sus normas reglamentarias de desarrollo. 
1. El sujeto activo que en Colombia es la DIAN (Dirección de Impuestos y Aduanas Nacionales), en España es la Agencia Tributaria.

2. El sujeto pasivo en los dos países son los contribuyentes que contraen la obligación de pagar el impuesto.

3. El hecho imponible o generador en Colombia se traduce en la obtención de ingresos que generen renta y en España la base imponible o hecho imponible en los rendimientos netos del trabajo, rendimientos de capital inmobiliario y mobiliario, rendimientos de actividades económicas y las ganancias y pérdidas patrimoniales.

4. En Colombia la base gravable es el monto al cual se le aplica la tarifa del impuesto según las características de los contribuyentes, en España la base liquidable es el resultado de restar a la base imponible las reducciones.

5. La tarifa en Colombia para las personas naturales se define de acuerdo con la tabla para el impuesto, 33\% para las personas jurídicas y 20\% para las personas jurídicas del régimen tributario especial; en España se denomina tipo de gravamen estatal especial destinado, como su nombre lo indica, al Estado y tipo de gravamen autonómico, que se destina a las comunidades autónomas.

6. Los descuentos en Colombia, que son aquellas cantidades que se pueden restar para disminuir el impuesto por pagar; en España la cuota tributaria es el resultado de aplicar a la base liquidable el tipo de gravamen estatal y el tipo de gravamen autonómico; con este se obtiene la cuota tributaria, a esta se le aplican unas reducciones especiales que se tomarían en este caso como descuento.

7. En España encontramos una figura que se denomina tributación conjunta o familiar que por medio de una sola declaración pueden pagar los cónyuges e hijos que cumplan los requisitos que la ley exige. Y existe la obligación declarar a todas las personas con derecho a deducciones por inversión en vivienda, cuenta ahorro-empresa doble imposición internacional o que hayan realizado aportaciones a patrimonios protegidos de las personas con discapacidad, planes de pensiones, planes de previsión asegurados o mutualidades de previsión social, planes de previsión social empresarial y seguros de dependencia que reduzcan la base imponible, cuando ejerciten tal derecho durante el pasado año. A estos hay que añadir quienes hayan disfrutado de las deducciones por maternidad y nacimiento o adopción. En Colombia declaran quienes superen los topes de ingresos, patrimonio y otros como consignaciones, compra con tarjeta de crédito, etc.

8. En Colombia hay tres clases de rentas clave dentro de la depuración del impuesto de renta, como son la renta presuntiva, la renta por comparación patrimonial y la renta líquida gravable; son tres procedimientos distintos que se hacen con el fin de llegar a una base del impuesto para hacer su respectiva determinación. En el territorio español encontramos dos tipos, renta general y renta del ahorro.

9. Al hacer la comparación entre el impuesto de renta en Colombia y en España, encontramos que hay rentas que en Colombia pueden estar gravadas y en España pueden presentar exenciones, o viceversa. Por ejemplo: en Colombia los ingresos por indemnización y por seguro de vida se encuentran exentos y en Españas se encuentran gravados los rendimientos del trabajo, las ayudas de contenido económico a los deportistas de alto nivel, las prestaciones por desempleo reconocidas por la respectiva entidad gestora cuando se perciban en la modalidad de pago único, los rendimientos del trabajo percibidos por trabajos efectivamente realizados en el extranjero, las ayudas de cualquier clase percibidas por los afectados por el virus de inmunodeficiencia humana. 
10. Las deducciones en Colombia, en España se denominan reducciones; hay reducciones que dependiendo del monto de salario que se reciba, se tiene derecho a reducir un porcentaje de dicho salario; hay una reducción por las cotizaciones que se hagan a los colegios de huérfanos o entidades similares, las cuotas satisfechas a sindicatos y colegios profesionales cuando la colegiación tenga carácter obligatorio, son reducibles también las aportaciones realizadas a planes de pensiones a favor de personas con discapacidad con un grado de minusvalía física o sensorial igual o superior a 65\%, psíquica igual - superior a $33 \%$, así como de personas que tengan una incapacidad declarada judicialmente con independencia de su grado.

11. Los descuentos, como los conocemos en Colombia, se llaman en España deducciones y algunas de estas son: deducción por maternidad, rentas del contribuyente por rendimientos 0 ganancias patrimoniales obtenidos y gravados en el extranjero.

12. Descuento tributario, el cual en España se denomina deducción; se encontró que hay ciertas similitudes y se busca que sus contribuyentes inviertan y estimulen la economía por medio de la inversión presente de distintas formas como, por ejemplo: en Colombia, por inversiones en acciones de sociedades agropecuarias, por reforestación. En España, inversión en vivienda habitual, deducción en actividades económicas, entre otras.

En España hay que destacar la deducción a quienes difundan y protejan el Patrimonio Histórico Español y de las ciudades, conjuntos y bienes declarados Patrimonio Mundial.

\section{CONCLUSIONES FINALES}

- El presente trabajo permitió compilar todas las normas y los antecedentes de la regulación tributaria del impuesto sobre la renta en Colombia y del que actualmente se aplica en España.

- Para España y Colombia, el impuesto de renta se declara y paga al final del período impositivo, normalmente un año, como una obligación tributaria principal tanto para personas naturales o jurídicas contribuyentes del impuesto.

- El impuesto sobre la renta en Colombia está compuesto de varios tipos de beneficios como son las rentas exentas, ingresos no constitutivos de renta, deducciones, y en España el impuesto sobre la renta solo presenta beneficios en cuanto a las deducciones y bonificaciones, los cuales benefician a personas físicas y a las sociedades.
- En España hay una división total en cuanto al impuesto sobre la renta de las personas físicas y el de sociedades ya que se encuentran contenidos en leyes distintas y su conformación es distinta, se hace más fácil su comprensión y por ende, no hay lugar a confusiones en cuanto a su depuración.

- Las comunidades autónomas en España son otra de las características más importantes del aparato tributario del país, ya que en el caso del impuesto de renta de las personas físicas, un porcentaje del impuesto se destina a la Comunidad Autónoma de donde procede la declaración, esto es algo positivo para las comunidades al entrar a participar del recaudo del impuesto y disponer de estos recursos para beneficio de los contribuyentes de la comunidad. 


\section{BIBLIOGRAFÍA}

Constitución Política de Colombia (1991).

Constitución Política de España (1978).

Corredor, Alejo Jesús Orlando (2007). El impuesto de renta en Colombia. Medellín: Editorial CIJUF.

Cosciani Césare. Citado por Cruz de Quiñones, Lucy. Principios constitucionales de Derecho Tributario. Bogotá: XIII Jornadas de Derecho Tributario.2012, Cartagena, Colombia.

Fajardo Calderón, Constanza Loreth; Suárez Amaya, Dora Cecilia (2010). El impuesto de renta. Obligaciones fiscales. Personas naturales - personas jurídicas. Armenia: Editorial Kinesis.

Fernández de Soto Blass, María Luisa (2005). Practicum del Derecho Tributario Español. Madrid: Editorial Dykinson.

Ferreiro Lapatza, José Juan. Curso de derecho financiero español. Marcial Pons ediciones jurídicas y sociales S.A.2006, Madrid, España.

Fino Serrano, Guillermo; Vasco Martínez, Rubén (1999). Elementos de la Tributación en Colombia. Medellín: Editorial CIJUF.
Guía Legis para declaración de renta (2010). Bogotá: Editorial Legis S.A.

Ley 35 del 28 de noviembre de 2006. "Del impuesto de las rentas sobre las personas físicas".

Ley 1082 de 2006. "Convenio entre el Reino de España y la Republica de Colombia para evitar la doble imposición y prevenir la evasión fiscal en materia de impuestos sobre la renta y sobre el patrimonio" y su "Protocolo", firmado en Bogotá, D.C., el 31 de marzo de 2005.

Martín Queralt, Juan; Lozano Serrano, Carmelo; Tejerizo López, José M. y Casado Ollero, Gabriel (2010). Curso de Derecho Financiero y Tributario. Editorial Tecnos.

Menéndez, Moreno Alejandro (2007). Derecho Financiero y tributario español. Valladolid: Editorial Lex Nova.

Modelo de Código del CIAT (Centro Interamericano de Administradores Tributarios) - art. 14.

Real Decreto 439/2007, de 30 de marzo, por el cual se aprueba el Reglamento del Impuesto sobre la Renta de las Personas Físicas y se modifica el Reglamento de Planes y Fondos de Pensiones, aprobado por el Real Decreto 304 de 2004 el 20 de febrero. 
